\title{
Correction to: Risk factors of premature rupture of membranes in public hospitals at Mekele city, Tigray, a case control study
}

Natnael Etsay Assefa*, Hailemariam Berhe, Fiseha Girma, Kidanemariam Berhe, Yodit Zewdie Berhe, Gdiom Gebreheat, Weldu Mamu Werid, Almaz Berhe, Hagos B Rufae and Guesh Welu

\section{Correction}

Following publication of the original article [1], the author reported that his name was misspelled. The original article has been corrected.

Incorrect name: Gidiom Gebrehet

Correct name: Gdiom Gebreheat

Published online: 16 October 2018

\section{Reference}

1. Assefa, et al. Risk factors of premature rupture of membranes in public hospitals at Mekele city, Tigray, a case control study. BMC Pregnancy and Childbirth. 2018;18:386. https://doi.org/10.1186/s12884-018-2016-6.

\footnotetext{
* Correspondence: natty416@gmail.com

Adigrat University College of Health Sciences, Adigart, Tigray, Ethiopia
} 